\title{
Proxalutamide Reduction of Mortality Rate in Hospitalized COVID-19 Patients Depends on Treatment Duration - an Exploratory Analysis of the Proxa-Rescue AndroCoV Trial
}

Ricardo Ariel Zimerman, $\mathrm{MD}_{1}$, Daniel do Nascimento Fonseca, $\mathrm{MD}_{2}$, Michael do Nascimento Correia, $\mathrm{MD}_{3}$, Renan Nascimento Barros, $\mathrm{MD}_{4}$, Dirce Costa Onety, $\mathrm{MD}_{5}$, Karla Cristina Petruccelli Israel, $\mathrm{MD}_{5,6}$, Emilyn Oliveira Guerreiro 2 , José Erique Miranda Medeiros, Raquel Neves Nicolau 2 , Luiza Fernanda Mendonça Nicolau, Rafael Xavier Cunha 2 , Maria Fernanda Rodrigues Barroco 2 , Patrícia Souza da Silva, Raysa Wanzeller de Souza Paulain, $\mathrm{MD}_{4}$, Claudia Elizabeth Thompson, $\mathrm{PhD}_{7}$, Andy Goren, $\mathrm{MD}_{8}$, Carlos Gustavo Wambier, $\mathrm{MD}, \mathrm{PhD}_{9}$, Flávio Adsuara Cadegiani, $\mathrm{MD}$, $\mathrm{PhD}_{8,10}$ *

${ }_{1}$ Hospital da Brigada Militar, Porto Alegre, Brazil

${ }_{2}$ Samel \& Oscar Nicolau Hospitals, Manaus, Brazil

${ }_{3}$ Hospital Regional José Mendes, Itacoatiara, Amazonas, Brazil

${ }_{4}$ Hospital Municipal Jofre Cohen, Parintins, Amazonas, Brazil

${ }_{5}$ Centro de Doenças Renais do Amazonas, Manaus, Brazil

${ }_{6}$ Programa de Pós-Graduação em Medicina Tropical - FMT/UEA, Manaus, Brazil

${ }_{7}$ Department of Pharmacosciences, Universidade Federal de Ciências da Saúde de Porto Alegre

${ }_{8}$ Applied Biology, Inc. Irvine, CA, USA.

${ }_{9}$ Department of Dermatology, Alpert Medical School of Brown University, Providence, RI, USA.

${ }_{10}$ Corpometria Institute, Brasilia, Brazil.

\section{*Corresponding author:}

Flavio Adsuara Cadegiani, $\mathrm{MD}, \mathrm{PhD}$

Applied Biology, Inc.

17780 Fitch

Irvine, CA 92614

f.cadegiani@gmail.com

Abstract Word Count: 449

Text-Only Word Count: 2397

Total Number of References: 24

Tables (\#): 3

Figures (\#): 2

Keywords: SARS-CoV-2, COVID-19, sepsis, proxalutamide, non-steroidal antiandrogen (NSAA), TMPRSS2. 


\section{Abstract}

Introduction: Proxalutamide, a second-generation non-steroidal antiandrogen (NSAA), primarily developed for castration-resistant prostate cancer, demonstrated reduction in 28-day mortality rate of $77.7 \%$ in hospitalized COVID-19 patients in a double-blind, placebo-controlled, two-arm randomized clinical trial (RCT), through intention-to-treat (ITT) analysis. We observed a high 28-day mortality rate of patients that did not complete the 14-day treatment with proxalutamide, compared to the placebo arm. These differences may raise hypotheses to explain the wide differences between ITT and ontreatment (OT) analysis in terms of efficacy. Despite the inherent limitations of OT analysis, we aimed to respond to unanswered questions regarding the drug efficacy when the 14-day treatment with proxalutamide was complete, and secondarily understand the causality relationship between treatment interruption and mortality rate.

Methods: This is a post-hoc exploratory analysis of a double-blinded, randomized, placebo-controlled, prospective, multicentric, two-arm RCT of 300mg-daily 14-day proxalutamide therapy for hospitalized COVID-19 patients not requiring mechanical ventilation. OT population excluded patients that did not complete the full 14-day course of therapy or died from COVID-19 complications within 24 hours of randomization. The primary outcome was the 28-day COVID-19 mortality rate. Secondary outcomes included median hospital length, 14-day and 28-day alive hospital discharge rate and 28-day all-cause mortality rate of those who discontinued intervention.

Results: In total, 580 patients completed the 14-day treatment or died during treatment, including 288 patients in the proxalutamide arm and 292 patients in the placebo arm, with similar baseline characteristics between groups. The 28-day COVID-19 mortality rate was $4.2 \%$ in the proxalutamide group and $49.0 \%$ in the placebo group. The mortality risk ratio (RR) was 0.08 (95\% CI, 0.05-0.15), with a number needed to treat (NNT) of 2.2 to prevent death. The median hospital length stay after randomization was 5 days (interquartile range [IQR] $=3$ to 7.2 days) in the proxalutamide group and 9 days (IQR $=6$ to 15 days) in the placebo group ( $\mathrm{p}<0.001)$. The 28-day all-cause mortality rate of patients that received proxalutamide but interrupted treatment before 14 days was $79.3 \%$, while those that received placebo and interrupted before 14 days was $52.8 \%$ ( $\mathrm{p}=0.054$ between groups).

Conclusion: The reduction in 28-day all-cause mortality rate with 14-day proxalutamide treatment for hospitalized COVID-19 patients was more significant while on treatment adhesion (92\%), compared to the reduction when all patients enrolled in the proxalutamide arm were considered (77.7\%). However, the magnitude of statistical significance of the reduction in all-cause mortality and the NNT were similar between the OT and ITT analysis. The apparent high mortality risk rate with early interruption of proxalutamide treatments suggests that strategies for treatment compliance should be reinforced for future RCTs with proxalutamide. (NCT04728802) 


\section{Introduction}

The identification of potential molecules that reduces severe acute respiratory syndrome coronavirus 2 (SARS-CoV-2) infectivity and pathogenicity and coronavirus disease 2019 (COVID-19) severity is critical while the COVID-19 pandemics is not fully controlled. While vaccines are considered as the most efficient public health measure to reduce COVID-19 mortality preventively, we still struggle to find effective drugs to reduce COVID-19 poorer outcomes among those already infected. ${ }^{1}$

The transmembrane protease serine 2 (TMPRSS2) is a key enzyme for viral cell entry, since it primes SARS-CoV-2 spike proteins to allow for a more efficient subsequent binding to membrane-attached angiotensin-converting enzyme 2 (ACE2) receptors. ${ }^{1}$ The only known endogenous modulators of TMPRSS2 expression are androgens. Antiandrogens are promising agents against COVID-19 due to their potential actions in the blockage of the entrance of the SARS-CoV-2 into the cells, through the inhibition of TMPRSS2 expression. ${ }^{2,3}$

Early observations in COVID-19 pandemic have identified hyperandrogenic phenotypes as independent risk factors for disease severity in both males ${ }^{4-6}$ and females. ${ }^{7-9}$ Antiandrogens have mechanistic plausibility to work against SARS-CoV-2, ${ }^{10,11}$ have demonstrated pre-clinical ${ }^{12-14}$ and preliminary clinical efficacy against COVID-19, both when used continuously ${ }^{15-17}$ or initiated during the course of the disease. ${ }^{18}$

Proxalutamide is a second-generation non-steroidal antiandrogen (NSAA), primarily developed for castration-resistant prostate cancer, that demonstrated high potency as an androgen receptor (AR) antagonist. Proxalutamide also acts as a suppressor of AR gene expression and regulates the angiotensin converting enzyme-2 (ACE-2). ${ }^{19}$

We have previously demonstrating that proxalutamide was effective to prevent hospitalization in COVID-19 male patients and to reduce viral shedding and inflammatory response, in a double-blind, placebo-controlled randomized clinical trial $(\mathrm{RCT}){ }^{20,21}$

We have also demonstrated that proxalutamide was able to reduce mortality rate by 77.7\% in moderate-to-severe hospitalized COVID-19 patients that were not on mechanical ventilation, and increased recovery speed by $128 \%$, when compared to placebo, also in a double-blind, placebo-controlled RCT.

The efficacy of proxalutamide in hospitalized COVID-19 patients was demonstrated using intention-to-treat (ITT) analysis that did not require any type of adjustment. The unmodified ITT is the gold standard method of evaluation to demonstrate efficacy and is more conservative, since ITT analysis includes subjects that discontinued treatment. 
Of the 645 patients enrolled in the trial, 65 discontinued or withdrew, including 29 of 317 subjects $(9.1 \%)$ of the proxalutamide arm and 36 of 328 subjects $(11.0 \%)$ of the placebo arm. ${ }^{22}$ The 28-day mortality rate was overwhelmingly high among those that interrupted proxalutamide (79.3\% mortality rate - 23 out of 29 patients), while the mortality rate for those who interrupted placebo was $50.0 \%$ (18 out of 36 patients), ${ }^{22}$ similar to the observed in the overall placebo arm. Importantly, placebo non-compliant patients exhibited similar mortality rate when compared to both overall placebo arm of the trial and in-hospital mortality in the same places where the trial was conducted. ${ }^{23}$

The intriguing high mortality of patients that did not complete the proxalutamide treatment led us to hypothesize that drug efficacy when used appropriately for 14 days could be different from the efficacy observed in ITT analysis. To evaluate those subjects that completed treatment or that died during treatment only, an on-treatment (OT) analysis would be recommended, although it may not allow conclusions regarding the actual drug efficacy.

The objective of the present post-hoc exploratory analysis is to evaluate the efficacy of proxalutamide in COVID-19 hospitalized patients when 14-day treatment is completed or uninterrupted until death, in case death occurs before 14 days of treatment. In addition, we describe the consequences in terms of outcomes of shorter duration proxalutamide treatment. 


\section{Methods}

This is a post-hoc analysis of a double-blinded, randomized, placebo-controlled, prospective, two-arm $\mathrm{RCT}^{22}$ describing the results of the RCT restricted to OT analysis, i.e., excluding patients that discontinued treatment before 14 days of drug treatment.

A detailed description of the trial design, sample size calculation, settings, recruitment, patient selection criteria, randomization, blinding, procedures and statistical analysis are published in another manuscript and detailed elsewhere. ${ }^{22}$

The trial was conducted at eight centers in six cities of the state of Amazonas, Brazil. Patients were recruited between February 1 and March 17, 2021. The RCT was registered in clinicaltrials.gov (NCT04728802), and approved by Brazilian National Ethics Committee (Approval number \#4.513.425; CAAE: 41909121.0.0000.5553; Comitê de Ética em Pesquisa (CEP) of the Comitê Nacional de Ética em Pesquisa (CONEP) of the Ministry of Health (MS)) (CEP/CONEP/MS).

\section{Selection criteria}

Selection criteria included subjects hospitalized due to COVID-19, not in mechanical ventilation, with positive real-time reverse transcription polymerase chain reaction (rtPCR) (Roche, USA) for SARS-CoV-2 within seven days, and, upon randomization, without class III or IV congestive heart failure (New York Heart Association), immunosuppression, baseline alanine transferase (ALT) above five times ULN (> 250 $\mathrm{U} / \mathrm{L}$ ), creatinine above $2.5 \mathrm{mg} / \mathrm{ml}$, and not currently using antiandrogen drugs, and, in case of women, not pregnant or planning to become pregnant within 90 days and nor breastfeeding.

\section{Procedures}

Patients were randomized to receive either proxalutamide $300 \mathrm{mg} /$ day plus usual care or a placebo plus usual care, for 14 days, in a 1:1 ratio.

The COVID-19 8-point ordinal scale was used to determine disease severity. The scale was employed during screening (day 0 ), on a daily basis on days $1-14$, day 21 , and day 28 . The clinical score was defined as: 8 . Death; 7 . Hospitalized, on invasive mechanical ventilation; 6. Hospitalized, on non-invasive ventilation or high flow oxygen devices; 5 . Hospitalized, requiring supplemental oxygen; 4. Hospitalized, not requiring supplemental oxygen- requiring ongoing medical care (COVID-19 related or otherwise); 3. Hospitalized, not requiring supplemental oxygen - no longer requires ongoing medical care; 2. Not hospitalized, limitation on activities; and 1. Not hospitalized, no limitations on activities. ${ }^{24}$

Patients discharged before the end of treatment continued the treatment at home until 14 days and were actively monitored for treatment compliance by daily phone calls. Participants discharged from the hospital were evaluated until day 28. Patients were 
instructed to contact or visit the same institution in case of relapse or new symptoms. Hospital readmissions were actively surveilled in all sites.

Baseline characteristics, previous medical history, and concomitant medications were recorded for each patient. Proxalutamide $300 \mathrm{mg} / \mathrm{day}$ ( 3 tablets of $100 \mathrm{mg}$ a day) or placebo ( 3 tablets a day) plus usual care was given for 14 days, even when COVID-19 remission occurred before this period. Usual care included medications such as enoxaparin, colchicine, methylprednisolone, dexamethasone, or antibiotic therapy if necessary.

\section{Outcomes}

The primary outcome measure was the COVID-19 mortality rate at 28 days under OT analysis. The secondary endpoints included hospitalization length duration (days), the recovery rate, which was defined as achieving alive hospital discharge (scores 1 and 2) at day 14 and 28 under OT analysis. We also compared 28-day mortality rate between non-treatment completers of the proxalutamide versus placebo arm, as well as the differences between the present OT analysis and the ITT analysis, published elsewhere. $^{22}$

\section{Statistical Analysis}

Risk ratios (RR) and confidence interval (CI) were calculated for recovery and mortality rates, Cox proportional hazards model was used to calculate hazard ratio (HR) and CI for all-cause mortality at day 28 , the Wilcoxon rank sum test was used for ordinal scale scores at 14 and 28 days, Kaplan-Meier's survivor function was used to evaluate and illustrate mortality and recovery rates over the 28 days after randomization. Statistical significance was defined as $\mathrm{P}<0.05$. Statistical analysis was performed in Stata/SE version 16.1 for Mac (StataCorp LLC, College Station, TX, USA). 


\section{Results}

\section{Subjects}

In total, 580 patients completed the 14-day treatment or died during treatment. Of these, 288 patients were treated with proxalutamide, including 163 males $(56.7 \%)$ and 125 females (43.3\%), and 292 patients received placebo, including 166 males (56.8\%) and 126 females (43.2\%). This population was considered for the OT analysis. A chart describing the patient flow of the OT population study is shown in Figure 1.

The baseline characteristics of the study population OT are described in Table 1 . The median age was 50.0 years (inter-quartile range, 39.0 to 61.0) Hypertension, type 2 diabetes mellitus (T2DM) and chronic obstructive pulmonary disorder (COPD) were present in $25.1 \%, 11.7 \%$, and $2.1 \%$ of the patients, and the body mass index (BMI) was above 30 in $8.0 \%$ of patients. No comorbidities, one comorbidity, and two or more comorbidities were present in $69.2 \%, 17.1 \%$, and $13.1 \%$, of the patients, respectively. Median time from hospitalization to randomization was 2.0 days (inter-quartile range, 1.0 to 4.0). The ordinal scale score at baseline were 6 (hospitalized on high-flow oxygen or non-invasive ventilation), 5 (hospitalized with oxygen use), and 4 (hospitalized with no oxygen use, but requiring medical care) in $66.4 \%, 30.5 \%$, and $2.7 \%$ of the patients, respectively. Median age, prevalence of comorbidities, number of comorbidities, median time from hospitalization to randomization, and distribution of ordinal scale score were similar between proxalutamide and placebo groups, and were also similar between per protocol and intent-to-treat cohorts.

Enoxaparin, omeprazole were administered to $100 \%$ of patients. Ceftriaxone, macrolides (azithromycin, clarithromycin) and colchicine were given to 99.3\%, 97.6\%, and $64.8 \%$ of patients receiving proxalutamide, and $99.0 \%, 99.3 \%$, and $92.6 \%$ of patients receiving placebo, respectively. All concomitant medications were used at similar proportions between the groups, except for colchicine ( $\mathrm{p}<0.001)$. 
medRxiv preprint doi: https://doi.org/10.1101/2021.06.28.21259661; this version posted July 13, 2021. The copyright holder for this preprint (which was not certified by peer review) is the author/funder, who has granted medRxiv a license to display the preprint in perpetuity.

It is made available under a CC-BY-NC-ND 4.0 International license .

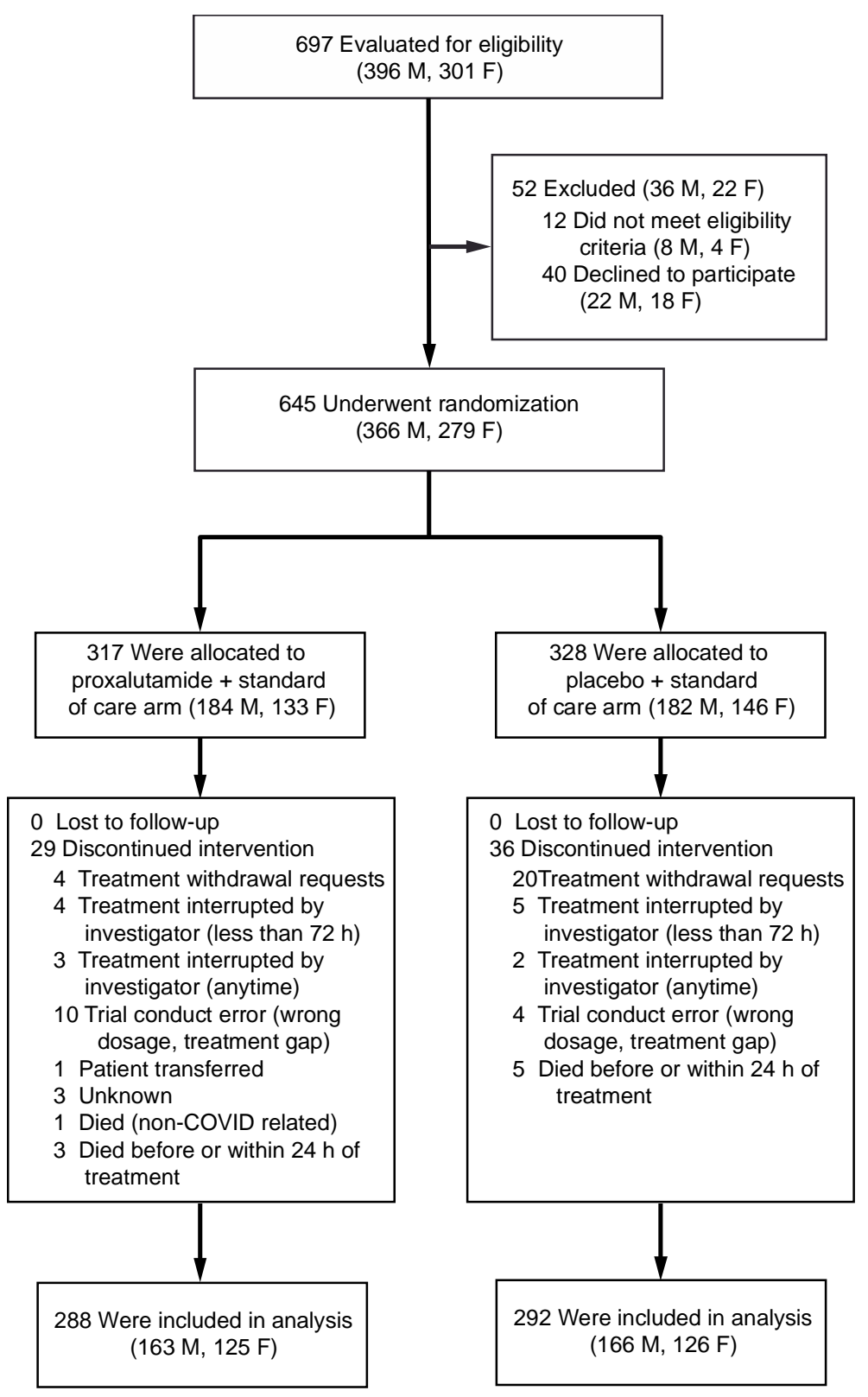

Figure 1. Enrollment, randomization, and analysis of the on-treatment (OT) population. 
medRxiv preprint doi: https://doi.org/10.1101/2021.06.28.21259661; this version posted July 13, 2021. The copyright holder for this preprint (which was not certified by peer review) is the author/funder, who has granted medRxiv a license to display the preprint in perpetuity.

It is made available under a CC-BY-NC-ND 4.0 International license .

Table 1. On-treatment baseline clinical characteristics, comorbidities, and concomitant medications.

\begin{tabular}{|c|c|c|c|c|}
\hline \multicolumn{5}{|c|}{ ON-TREATMENT } \\
\hline Characteristic & $\begin{array}{c}\text { Overall } \\
N=580\end{array}$ & $\begin{array}{l}\text { Proxalutamide } \\
\qquad N=288\end{array}$ & $\begin{array}{c}\text { Placebo } \\
N=292\end{array}$ & $\mathbf{P}$ \\
\hline \multicolumn{5}{|l|}{ Age } \\
\hline Median - years (IQR) & $50(39-61)$ & $50(41-61)$ & $50(38-62)$ & $n / s$ \\
\hline \multicolumn{5}{|l|}{ Sex-no. (\%) } \\
\hline Female & $250(43.1 \%)$ & $125(43.4 \%)$ & $126(43.2 \%)$ & \multirow[t]{2}{*}{$n / s$} \\
\hline Male & $330(56.9 \%)$ & $163(56.6 \%)$ & $166(56.8 \%)$ & \\
\hline $\mathrm{BMI}>30-$ no. (\%) & $47(8.1 \%)$ & $24(8.3 \%)$ & $23(7.9 \%)$ & $n / s$ \\
\hline Hypertension - no. (\%) & $156(26.9 \%)$ & $81(28.1 \%)$ & $75(25.7 \%)$ & $n / s$ \\
\hline Type 2 diabetes mellitus - no. (\%) & 70 (12.1\%) & $34(11.8 \%)$ & $36(12.3 \%)$ & $n / s$ \\
\hline COPD - no. (\%) & $11(1.9 \%)$ & $4(1.4 \%)$ & $7(2.4 \%)$ & $n / s$ \\
\hline Chronic kidney disease - no. (\%) & $0(0 \%)$ & $0(0 \%)$ & $0(0 \%)$ & $n / s$ \\
\hline \multicolumn{5}{|l|}{ Coexisting conditions - no. (\%) } \\
\hline 0 & $391(67.4 \%)$ & $190(66.0 \%)$ & $201(68.8 \%)$ & $n / s$ \\
\hline 1 & $111(19.1 \%)$ & $61(21.2 \%)$ & $50(17.1 \%)$ & $n / s$ \\
\hline $2+$ & $78(13.4 \%)$ & $37(12.8 \%)$ & $41(14.0 \%)$ & $n / s$ \\
\hline $\begin{array}{l}\text { Median time from hospitalization to } \\
\text { randomization (IQR) - days }\end{array}$ & $2.0(1.0-4.0)$ & $2.0(1.0-4.0)$ & $2.0(1.0-4.0)$ & $n / s$ \\
\hline Score on the COVID-19 ordinal scale- no. (\%) & & & & $n / s$ \\
\hline $\begin{array}{l}\text { 3. Hospitalized, not requiring } \\
\text { supplemental oxygen - no longer } \\
\text { requires ongoing medical care }\end{array}$ & $2(0.3 \%)$ & 0 & $2(0.7 \%)$ & $n / s$ \\
\hline $\begin{array}{l}\text { 4. Hospitalized, not requiring } \\
\text { supplemental oxygen, requiring } \\
\text { ongoing medical care (COVID-19 } \\
\text { related or otherwise) }\end{array}$ & $16(2.8 \%)$ & $7(2.4 \%)$ & $9(3.1 \%)$ & $n / s$ \\
\hline $\begin{array}{l}\text { 5. Hospitalized, requiring } \\
\text { supplemental oxygen }\end{array}$ & $179(30.9 \%)$ & 89 (30.9\%) & $90(30.8 \%)$ & $n / s$ \\
\hline $\begin{array}{l}\text { 6. Hospitalized, receiving non-invasive } \\
\text { ventilation or high flow oxygen } \\
\text { devices }\end{array}$ & $383(66.0 \%)$ & $192(66.7 \%)$ & $191(65.4 \%)$ & $n / s$ \\
\hline \multicolumn{5}{|l|}{ Concomitant medications - no. (\%) } \\
\hline Ceftriaxone & $575(99.1 \%)$ & $286(99.3 \%)$ & $289(99.0 \%)$ & $n / s$ \\
\hline Colchicine & $459(79.1 \%)$ & $187(64.9 \%)$ & $272(93.1 \%)$ & $<0.001$ \\
\hline Enoxaparin & 590 (100\%) & $288(100 \%)$ & $292(100 \%)$ & $n / s$ \\
\hline $\begin{array}{l}\text { Glucocorticosteroids } \\
\text { (dexamethasone, } \\
\text { methylprednisolone) }\end{array}$ & 590 (100\%) & $288(100 \%)$ & 292 (100\%) & $n / s$ \\
\hline $\begin{array}{l}\text { Macrolides (azithromycin, } \\
\text { clarithromycin) }\end{array}$ & $571(98.4 \%)$ & 281 (97.6\%) & 290 (99.3\%) & $n / s$ \\
\hline Omeprazole & $590(100 \%)$ & $288(100 \%)$ & $292(100 \%)$ & $n / s$ \\
\hline
\end{tabular}


medRxiv preprint doi: https://doi.org/10.1101/2021.06.28.21259661; this version posted July 13, 2021. The copyright holder for this preprint (which was not certified by peer review) is the author/funder, who has granted medRxiv a license to display the preprint in perpetuity.

It is made available under a CC-BY-NC-ND 4.0 International license .

$\mathrm{BMI}=$ Body mass index $\mathrm{COPD}=$ Chronic obstructive pulmonary disease

\section{ON-TREATMENT}

\section{Efficacy Outcomes}

Table 2 describes the primary and secondary outcomes OT, and Figure 2 illustrates the Kaplan-Meier curves of the outcomes from randomization until day 28.

The 28-day COVID-19 mortality rates were $4.2 \%$ for the proxalutamide arm and $49 \%$ for the placebo arm. The 28-day COVID-19 mortality ratio was 0.08 (95\% CI, 0.05$0.15)$ at day 28.

The median hospital length stay was eight days (IQR, 6 to 12) in the proxalutamide group and 12 days (IQR, 8 to 19 ) in the placebo group ( $<<0.001$ ). When considering the number of hospitalization days since beginning of treatment, median duration was five (IQR, 3 to 7.2) and nine days (IQR, 6 to 15$)$ in the proxalutamide and placebo groups, respectively.

After 14 days, distribution of disease burden was significantly different between proxalutamide and placebo $(\mathrm{p}<0.001)$. Among 288 patients from the proxalutamide group, six (2.1\%) died until day 14, and 113 (38.7\%) of the 292 patients from the placebo group died by day 14 (p < 0.001). At day 28, $12(4.2 \%)$ and $143(49.0 \%)$ patients died from the proxalutamide and placebo groups, respectively $(\mathrm{p}<0.001)$. The mortality risk ratio was 0.05 (95\% CI, 0.02-0.12) at day 14 .

Recovery rates were $88.2 \%$ and $92.4 \%$ in the proxalutamide group at days 14 and 28 , and $35.3 \%$ and $47.3 \%$ in the placebo group, respectively. The recovery rate ratio was 2.50 (95\%CI, 2.13-2.94) at day 14 and 1.95 (95\% CI, 1.72-2.21) at day 28, favorable for proxalutamide versus placebo.

The 28-day all-cause mortality rate of patients receiving proxalutamide that interrupted the 14-day proxalutamide treatment at least 24 hours before death $(79.3 \% ; 23$ deaths of 29 patients) was marginally significantly higher than the 28-day mortality rate of noncompliant patients that were receiving placebo $(52.8 \%$; 19 deaths of 36 patients $)(\mathrm{p}=$ $0.058)$. 
medRxiv preprint doi: https://doi.org/10.1101/2021.06.28.21259661; this version posted July $13,2021$. The copyright holder for this preprint (which was not certified by peer review) is the author/funder, who has granted medRxiv a license to display the preprint in perpetuity.

It is made available under a CC-BY-NC-ND 4.0 International license .

\begin{tabular}{|c|c|c|c|c|}
\hline & $\begin{array}{c}\text { Overall } \\
\mathrm{N}=580 \\
\text { Females }=251 \\
\text { Males }=329\end{array}$ & $\begin{array}{l}\text { Proxalutamide } \\
\qquad \mathrm{N}=288 \\
\text { Females }=125 \\
\text { Males }=163\end{array}$ & $\begin{array}{c}\text { Placebo } \\
\mathrm{N}=292 \\
\text { Females }=126 \\
\text { Males }=166\end{array}$ & p \\
\hline $\begin{array}{r}\text { Score on the COVID-19 ordinal scale at Day } \\
14-\text { no. (\%) }\end{array}$ & & & & $<0.001$ \\
\hline 1. Not hospitalized, no limitations on activities & $239(41.2 \%)$ & $213(74.1 \%)$ & $26(8.9 \%)$ & $<0.001$ \\
\hline 2. Not hospitalized, limitation on activities & $118(20.3 \%)$ & $41(14.2 \%)$ & $77(26.4 \%)$ & 0.014 \\
\hline $\begin{array}{l}\text { 3. Hospitalized, not requiring supplemental } \\
\text { oxygen - no longer requires ongoing medical } \\
\text { care }\end{array}$ & $12(2.1 \%)$ & $3(1.0 \%)$ & $9(3.1 \%)$ & 0.67 \\
\hline $\begin{array}{l}\text { 4. Hospitalized, not requiring supplemental } \\
\text { oxygen, requiring ongoing medical care }\end{array}$ & $24(4.1 \%)$ & $10(3.5 \%)$ & $14(4.8 \%)$ & 0.78 \\
\hline 5. Hospitalized, requiring supplemental oxygen & $23(4.0 \%)$ & $11(3.8 \%)$ & $12(4.1 \%)$ & 0.95 \\
\hline $\begin{array}{l}\text { 6. Hospitalized, receiving non-invasive } \\
\text { ventilation or high flow oxygen devices }\end{array}$ & $7(1.2 \%)$ & $1(0.3 \%)$ & $6(2.0 \%)$ & 0.72 \\
\hline $\begin{array}{r}\text { 7. Hospitalized, on invasive mechanical } \\
\text { ventilation }\end{array}$ & $38(6.6 \%)$ & $3(1.0 \%)$ & $35(12.0 \%)$ & 0.023 \\
\hline 8. Death & $119(20.5 \%)$ & $6(2.1 \%)$ & $113(38.7 \%)$ & $<0.001$ \\
\hline $\begin{array}{r}\text { Score on the COVID-19 ordinal scale at Day } \\
14-\text { Median (IQR) }\end{array}$ & $2(1-7)$ & $1(1-2)$ & $7(2-8)$ & $<0.001$ \\
\hline $\begin{array}{r}\text { Score on the COVID-19 ordinal scale at Day } \\
\text { 28-Median (IQR) }\end{array}$ & $1(1-8)$ & $1(1-1)$ & $7(2-8)$ & $<0.001$ \\
\hline $\begin{array}{l}\text { Recovery at } 14 \text { days } \\
\qquad \text { (recovery = scores } 1 \text { and } 2 \text { ) }\end{array}$ & $357(61.6 \%)$ & $254(88.2 \%)$ & $103(35.3 \%)$ & $<0.001$ \\
\hline Females $-\mathrm{n}(\%)$ & $153(61.0 \%)$ & $109(87.2 \%)$ & $44(34.9 \%)$ & $<0.001$ \\
\hline Males - n (\%) & $204(62.0 \%)$ & $145(89.0 \%)$ & $59(35.5 \%)$ & $<0.001$ \\
\hline Recovery rate ratio $(95 \% \mathrm{CI})$ & \multicolumn{4}{|c|}{$2.50(2.13-2.94)$} \\
\hline $\begin{array}{l}\text { Recovery at } 28 \text { days } \\
\qquad \text { (recovery }=\text { scores } 1 \text { and } 2 \text { ) }\end{array}$ & $404(69.6 \%)$ & $266(92.4 \%)$ & $138(47.3 \%)$ & $<0.001$ \\
\hline Females - $\mathrm{n}(\%)$ & $178(70.9 \%)$ & $116(92.8 \%)$ & $62(49.2 \%)$ & $<0.001$ \\
\hline Males - n (\%) & $226(68.7 \%)$ & $150(92.0 \%)$ & $76(45.8 \%)$ & $<0.001$ \\
\hline Recovery rate ratio $(95 \% \mathrm{CI})$ & \multicolumn{4}{|c|}{$1.95(1.72-2.21)$} \\
\hline COVID-19 mortality at 14 days & $119(20.5 \%)$ & $6(2.1 \%)$ & $113(38.7 \%)$ & $<.001$ \\
\hline Females $-\mathrm{n}(\%)$ & $47(18.8 \%)$ & $4(3.2 \%)$ & $43(34.1 \%)$ & $<.001$ \\
\hline Males - n (\%) & $72(21.8 \%)$ & $2(1.2 \%)$ & $70(42.2 \%)$ & $<.001$ \\
\hline Mortality risk ratio $(95 \% \mathrm{CI})$ & \multicolumn{4}{|c|}{$0.05(0.02-0.12)$} \\
\hline COVID-19 mortality at 28 days & $155(26.7 \%)$ & $12(4.2 \%)$ & $143(49.0 \%)$ & $<.001$ \\
\hline Females $-\mathrm{n}(\%)$ & $65(26.0 \%)$ & $5(4.0 \%)$ & $60(47.6 \%)$ & $<.001$ \\
\hline Males - n (\%) & $90(27.3 \%)$ & $7(4.3 \%)$ & $83(50.0 \%)$ & $<.001$ \\
\hline Mortality risk ratio $(95 \% \mathrm{Cl})$ & \multicolumn{4}{|c|}{$0.08(0.05-0.15)$} \\
\hline Median hospitalization days (IQR) & $\begin{array}{c}10 \\
(6-16)\end{array}$ & $\begin{array}{c}8 \\
(6-12)\end{array}$ & $\begin{array}{c}12 \\
(8-19)\end{array}$ & $<.001$ \\
\hline $\begin{array}{l}\text { Median hospitalization days after } \\
\text { randomization (IQR) }\end{array}$ & $\begin{array}{c}7 \\
(4-12)\end{array}$ & $\begin{array}{c}5 \\
(3-7.2)\end{array}$ & $\begin{array}{c}9 \\
(6-15)\end{array}$ & $<.001$ \\
\hline
\end{tabular}

Table 2. Primary and secondary outcomes, on-treatment analysis.

Coronavirus disease 2019 8-point ordinal scale scores distribution at 14 days. Mortality (score 8), and recovery rates (scores 1 or 2 ) over 14 and 28 days after randomization (IQR = interquartile range, $\mathrm{CI}=$ confidence interval). 
medRxiv preprint doi: https://doi.org/10.1101/2021.06.28.21259661; this version posted July 13, 2021. The copyright holder for this preprint (which was not certified by peer review) is the author/funder, who has granted medRxiv a license to display the preprint in perpetuity.

It is made available under a CC-BY-NC-ND 4.0 International license .

Figure 2. Kaplan-Meier estimates in the on-treatment analysis from randomization to

Day 28.
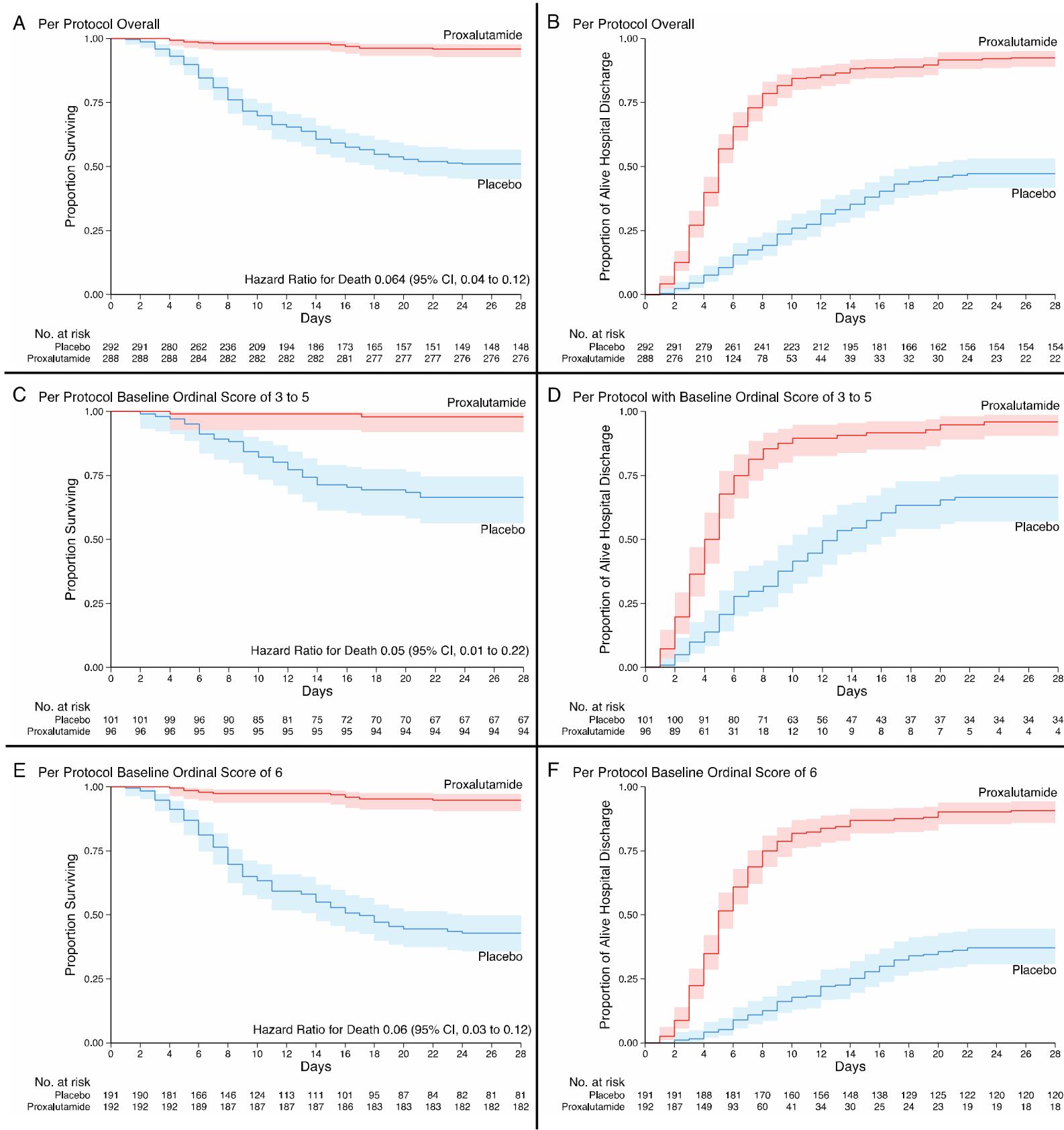

$\begin{array}{rlllllllllllllll}\text { No. at risk } & & & & & & & & & & & & & \\ \text { Placebo } & 292 & 291 & 279 & 261 & 241 & 223 & 212 & 195 & 181 & 166 & 162 & 156 & 154 & 154 & 154 \\ \text { Proxalutamide } & 288 & 276 & 210 & 124 & 78 & 53 & 44 & 39 & 33 & 32 & 30 & 24 & 23 & 22 & 22\end{array}$

D Per Protocol with Baseline Ordinal Score of 3 to 5

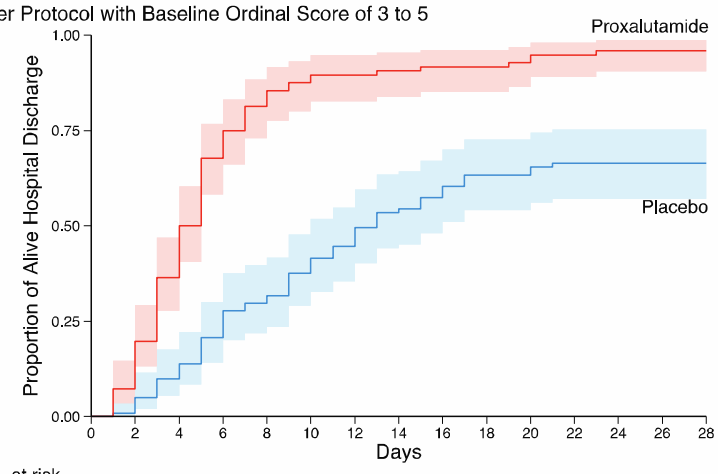

No. at risk

$\begin{array}{rccccccccccccccc}\text { Placebo } & 101 & 100 & 91 & 80 & 71 & 63 & 56 & 47 & 43 & 37 & 37 & 34 & 34 & 34 & 34 \\ \text { Proxalutamide } & 96 & 89 & 61 & 31 & 18 & 12 & 10 & 9 & 8 & 8 & 7 & 5 & 4 & 4 & 4\end{array}$

F Per Protocol Baseline Ordinal Score of 6

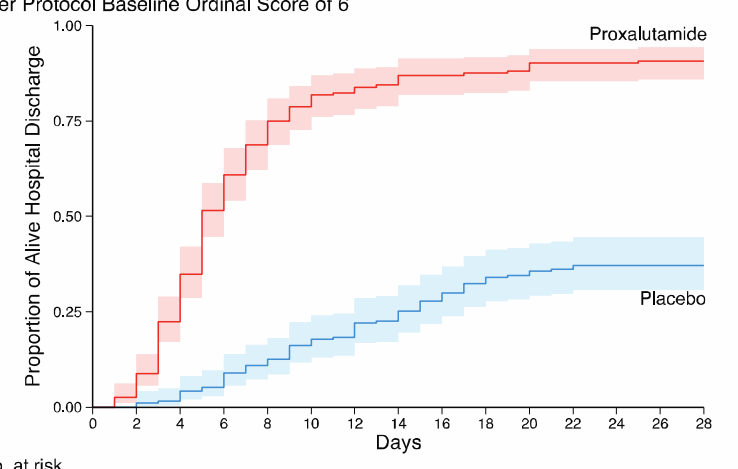

No. at risk

$\begin{array}{rlllllllllllllll}\text { Placebo } & 191 & 191 & 188 & 181 & 170 & 160 & 156 & 148 & 138 & 129 & 125 & 122 & 120 & 120 & 120 \\ \text { roxalutamide } & 192 & 187 & 149 & 93 & 60 & 41 & 34 & 30 & 25 & 24 & 23 & 19 & 19 & 18 & 18\end{array}$

Surviving (Panel A) and Alive Hospital Discharge (Panel B) for the overall population. Surviving (Panel C) and Alive Hospital Discharge (Panel D) for patients with baseline ordinal scale scores 3 to 5 .

Surviving (Panel E) and Alive Hospital Discharge (Panel F) for patients with baseline ordinal scale score 6. 


\section{Safety Outcomes}

Adverse events (AEs) observed in the population OT are detailed in Table 3. Number of subjects that experimented at least one adverse effect was higher in the placebo group $(64.4 \%)$ than in the proxalutamide group $(26.0 \%)(\mathrm{p}<0.001)$. Disease progression was more commonly observed in the placebo arm $(51.7 \%)$ than in the proxalutamide arm $(4.5 \%)$ ( $\mathrm{p}<0.001)$. Shock needing use of vasopressors was more common in the placebo group $(42.8 \%)$ than in the proxalutamide group $(1.4 \%)(\mathrm{p}<0.001)$. Liver or kidney injury was more commonly detected in the placebo group (12.0\%) than in the proxalutamide group $(1.7 \%)(\mathrm{p}=0.032)$. Among grades 2 and 1 AEs, diarrhea was the only AEs more commonly reported in the proxalutamide arm (16.3\%) than in the placebo arm $(3.1 \%)(\mathrm{p}=0.006)$. 
Table 3. On-treatment safety outcomes.

\begin{tabular}{|c|c|c|c|c|}
\hline Characteristic & Overall & Proxalutamide & Placebo & P \\
\hline Safety population & 580 & 288 & 292 & \\
\hline $\begin{array}{c}\text { Number of subjects with 1 or more } \\
\text { TEAE }\end{array}$ & $263(45.3 \%)$ & $75(26.0 \%)$ & $188(64.4 \%)$ & $<.001$ \\
\hline Grade 5 - n (\%) & & & & \\
\hline Death, Day 14 & $119(20.5 \%)$ & $6(2.1 \%)$ & $113(38.7 \%)$ & $<.001$ \\
\hline Death, Day 28 & $155(26.7 \%)$ & $12(4.2 \%)$ & $143(49.0 \%)$ & $<.001$ \\
\hline Grades 4 or 3 - n (\%) & & & & \\
\hline Shock, requiring vasopressors & $129(22.2 \%)$ & $4(1.4 \%)$ & $125(42.8 \%)$ & $<0.001$ \\
\hline Mechanical ventilation at Day 14 & $38(6.6 \%)$ & $3(1.0 \%)$ & $35(12.0 \%)$ & 0.023 \\
\hline Mechanical ventilation at Day 28 & $5(0.9 \%)$ & $1(0.3 \%)$ & $4(1.4 \%)$ & 0.83 \\
\hline Disease progression & $164(28.3 \%)$ & $13(4.5 \%)$ & $151(51.7 \%)$ & $<0.001$ \\
\hline Renal or liver injury & $40(6.9 \%)$ & $5(1.7 \%)$ & $35(12.0 \%)$ & 0.032 \\
\hline Renal failure & $20(3.4 \%)$ & $2(0.7 \%)$ & $18(6.2 \%)$ & 0.25 \\
\hline (creatinin increase > 100\%) & $20(3.4 \%)$ & $3(1.0 \%)$ & $17(5.8 \%)$ & 0.32 \\
\hline Hepatic damage & & & & \\
\hline (ALT > 250 U/L or > 100\% increase) & & & & 0.006 \\
\hline Grades 2 or 1 - n (\%) & $56(9.7 \%)$ & $47(16.3 \%)$ & $9(3.1 \%)$ & 0.88 \\
\hline Diarrhea & $4(0.7 \%)$ & $3(1.0 \%)$ & $1(0.3 \%)$ & 0.77 \\
\hline Abdominal pain & $4(0.7 \%)$ & $4(1.4 \%)$ & 0 & 0.76 \\
\hline Irritability & $4 / 329(1.2 \%)$ & $4 / 163(2.5 \%)$ & $0 / 166$ & 0.70 \\
\hline Spontaneous erection (males) & & & \\
\hline
\end{tabular}

Treatment emergent adverse events (TEAE) in the studied population.

ALT $=$ Alanine aminotransferase 


\section{Discussion}

Reduction of mortality with the use of proxalutamide $300 \mathrm{mg}$ daily for 14 days in hospitalized COVID-19 patients was not-negligently higher in the OT analysis $(95 \%$ and $92 \%$ reduction at days 14 and 28, respectively) than in the ITT (79\% and $78 \%$ reduction at days 14 and 28, respectively). ${ }^{22}$ The differences between ITT and OT occurred because the 28-day mortality rate of treatment non-completers, i.e., patients that did not complete the 14-day proxalutamide treatment or that died at least 24 hours before interruption, was extremely high $(79.3 \%)$, and substantially higher than noncompliant patients that were receiving placebo (52.8\%) and fully-compliant that received proxalutamide $(4.2 \%)$. We hypothesized that the sudden and early interruption of proxalutamide may have led to an overcompensating relapse of COVID-19 and its complications. The mortality rate in non-treatment compliance subjects reinforces the antiviral and indirect protective mechanisms of action of proxalutamide, as a sort of proof-of-concept, since its early removal was mostly fatal for patients. This also raises concern regarding the importance to comply to the period of use of 14 days.

Despite the important differences between the OT and ITT analysis, the NNT of proxalutamide for hospitalized COVID-19 patients to prevent death was numerically similar between OT and ITT analysis, of 2.2 and 2.6, respectively. The interpretation of the results of proxalutamide as being highly effective to prevent deaths in moderate-tosevere COVID-19 patients did not change between ITT and OT analyses.

This study has limitations inherent to post-hoc and retrospective analyses, although all the major barriers that could lead to confounding biases were addressed. ${ }^{25}$ Unbalanced actives and placebo distribution across sites and minor protocol modifications were the major weaknesses of the present RCT, while the lack of any modification of the ITT analysis prevented additional biases. ${ }^{21}$

The major confounding factor in the present analysis is the causality relationship between interrupting of treatment with proxalutamide and apparent higher mortality rate. Initially, differences in the mortality rate observed between the OT and ITT analysis could be due to the fact that patients tend to discontinue treatment in case of lack of response. Since the mortality rate was substantially lower in the proxalutamide arm compared to the placebo arm, and the number of non-completers was similar between these groups, similar increases in mortality rate would represent a higher increase in terms of percentage in the group with lower mortality rate, i.e., in the active arm.

However, treatment non-compliance in the placebo arm was not associated to poorer response compared to completers of the placebo arm. Conversely, non-completers of the proxalutamide arm had higher mortality rate compared to completers of the same arm 
and to the placebo arm. This reinforces the hypothesis of potential harm caused by abrupt and early interruption of proxalutamide.

Indeed, in the male outpatient trial with proxalutamide, ${ }^{20}$ the initial protocol was a 3-day treatment. However, after a few cases of disease relapse after the discontinuation, we increased the treatment duration to 7 days. In addition, in this trial, all 3 hospitalizations occur only after the end of the treatment with proxalutamide.

We reinforce the fact that the high mortality rate observed in non-compliance patients raised questions regarding the early interruption of proxalutamide, not only as an issue of no longer providing protection against SARS-CoV-2, but also the early discontinuation as being harmful and dangerous when duration of treatment is not respected. Since it is largely known that duration of a drug therapy is highly critical for its effects and outcomes, the comparisons between OT and ITT analysis and between early interruption of proxalutamide versus early interruption of placebo was necessary to highlight the importance of treatment duration with proxalutamide for moderate-tosevere COVID-19 explicit.

In addition to the message that the actual reduction of mortality rate with proxalutamide when treatment was fully complied is $92 \%$, the present work also conveys the message that further trials with proxalutamide must include in their consent form that a potential increased risk of mortality if treatment is interrupted before the proposed period of 14 days. This warning is of great ethics importance and is made necessary for any future study on the drug. Ongoing trials should consider amending their consent forms, warn enrolled patients of these potential increased risk of mortality, and ethics committees should be informed of this new finding for our RCT.

References

1. WHO Coronavirus (COVID-19) Dashboard | WHO Coronavirus Disease (COVID-19) Dashboard.

2. Hoffmann M, Kleine-Weber H, Schroeder S, et al. SARS-CoV-2 Cell Entry Depends on ACE2 and TMPRSS2 and Is Blocked by a Clinically Proven Protease Inhibitor. Cell [Internet] 2020;181(2):271-280.e8. Available from: https://linkinghub.elsevier.com/retrieve/pii/S0092867420302294

3. Lin B, Ferguson C, White JT, et al. Prostate-localized and androgen-regulated expression of the membrane-bound serine protease TMPRSS2. Cancer Res [Internet] 1999;59(17):4180-4. Available from: http://www.ncbi.nlm.nih.gov/pubmed/10485450

4. Wambier CG, Vaño-Galván S, McCoy J, Gomez-Zubiaur A, Herrera S, Hermosa-Gelbard Á, Moreno-Arrones OM, Jiménez-Gómez N, GonzálezCantero A, Fonda-Pascual P, Segurado-Miravalles G, Shapiro J, Pérez-García B, Goren A. Androgenetic alopecia present in the majority of patients hospitalized with COVID-19: The "Gabrin sign". J Am Acad Dermatol. 2020 
Aug;83(2):680-682. doi: 10.1016/j.jaad.2020.05.079. Epub 2020 May 22. PMID: 32446821; PMCID: PMC7242206.

5. Wambier CG, Vaño-Galván S, McCoy J, Pai S, Dhurat R, Goren A. Androgenetic alopecia in COVID-19: Compared to age-matched epidemiologic studies and hospital outcomes with or without the Gabrin sign. J Am Acad Dermatol. 2020 Dec;83(6):e453-e454. doi: 10.1016/j.jaad.2020.07.099. Epub 2020 Jul 29. PMID: 32735970; PMCID: PMC7387285

6. Cadegiani F, Lin EM, Goren A, Wambier CG. Potential risk for developing severe COVID-19 disease among anabolic steroid users. BMJ Case Rep. 2021 Feb 26;14(2):e241572. doi: 10.1136/bcr-2021-241572. PMID: 33637513; PMCID: PMC7919571.

7. Cadegiani FA, Lim RK, Goren A, McCoy J, Situm M, Kovacevic M, Vañó Galván S, Sinclair R, Tosti A, Wambier CG. Clinical symptoms of hyperandrogenic women diagnosed with COVID-19. J Eur Acad Dermatol Venereol. 2021 Feb;35(2):e101-e104. doi: 10.1111/jdv.17004. Epub 2020 Nov 8. PMID: 33089570.

8. Huffman AM, Rezq S, Basnet J, Yanes Cardozo LL, Romero DG. SARS-CoV-2 Viral Entry Proteins in Hyperandrogenemic Female Mice: Implications for Women with PCOS and COVID-19. Int J Mol Sci. 2021 Apr 25;22(9):4472. doi: 10.3390/ijms22094472. PMID: 33922918; PMCID: PMC8123333.

9. Subramanian A, Anand A, Adderley NJ, Okoth K, Toulis KA, Gokhale K, Sainsbury C, O'Reilly MW, Arlt W, Nirantharakumar K. Increased COVID-19 infections in women with polycystic ovary syndrome: a population-based study. Eur J Endocrinol. 2021 May;184(5):637-645. doi: 10.1530/EJE-20-1163. PMID: 33635829; PMCID: PMC8052516.

10. Wambier CG, Mehta N, Goren A, Cadegiani FA. COVID-19, androgens, and androgenetic alopecia. Derm Rev. 2020;1-8. First published: 23 December 2020/ DOI: https://doi.org/10.1002/der2.50

11. Cadegiani FA. Repurposing existing drugs for COVID-19: an endocrinology perspective. BMC Endocr Disord. 2020 Sep 29;20(1):149. doi: 10.1186/s12902020-00626-0. PMID: 32993622; PMCID: PMC7523486.

12. Wu S, Miao L, Zhou Q, et al. Suppression of Androgen Receptor (AR)ACE2/TMPRSS2 Axis by AR Antagonists May Be Therapeutically Beneficial for Male COVID-19 Patients. SSRN Electron J 2020;

13. Qiao Y, Wang XM, Mannan R, et al. Targeting transcriptional regulation of SARS-CoV-2 entry factors ACE2 and TMPRSS2. Proc Natl Acad Sci U S A 2020;118(1).

14. Li F, Han M, Dai P, et al. Distinct mechanisms for TMPRSS2 expression explain organ-specific inhibition of SARS-CoV-2 infection by enzalutamide. Nat Commun [Internet] 2021;12(1):866. Available from: http://www.nature.com/articles/s41467-021-21171-x

15. McCoy J, Cadegiani FA, Wambier CG, Herrera S, Vaño-Galván S, Mesinkovska NA, Ramos PM, Shapiro J, Sinclair R, Tosti A, Goren A. 5-alphareductase inhibitors are associated with reduced frequency of COVID-19 
symptoms in males with androgenetic alopecia. J Eur Acad Dermatol Venereol. 2021 Apr;35(4):e243-e246. doi: 10.1111/jdv.17021. Epub 2020 Nov 22. PMID: 33135263.

16. Goren A, Wambier CG, Herrera S, McCoy J, Vaño-Galván S, Gioia F, Comeche B, Ron R, Serrano-Villar S, Ramos PM, Cadegiani FA, Kovacevic M, Tosti A, Shapiro J, Sinclair R. Anti-androgens may protect against severe COVID-19 outcomes: results from a prospective cohort study of 77 hospitalized men. J Eur Acad Dermatol Venereol. 2021 Jan;35(1):e13-e15. doi: 10.1111/jdv.16953. Epub 2020 Oct 21. PMID: 32977363; PMCID: PMC7536996.

17. Kyung

Min Lee, Kent Heberer, Anthony Gao, Daniel J Becker, Stacy Loeb, Danil V.Makarov, Barbara Gulanski, Scott L DuVall, Mihaela Aslan, Jennifer Lee, Richard Hauger, Mei

Chiung Shih, Julie Lynch, Matthew Rettig. A population-level analysis of the protective effects of androgen deprivation therapy against COVID-19 disease incidence and severity. medRxiv 2021.05.10.21255146; doi:https://doi.org/10.1101/2021.05.10.212551 46

18. Cadegiani FA, McCoy J, Gustavo Wambier C, Goren A. Early Antiandrogen Therapy With Dutasteride Reduces Viral Shedding, Inflammatory Responses, and Time-to-Remission in Males With COVID-19: A Randomized, DoubleBlind, Placebo-Controlled Interventional Trial (EAT-DUTA AndroCoV Trial Biochemical). Cureus. 2021 Feb 1;13(2):e13047. doi: 10.7759/cureus.13047. PMID: 33643746; PMCID: PMC7885746.

19. Qu F, Gu Y, Wang Q, et al. Metabolomic profiling to evaluate the efficacy of proxalutamide, a novel androgen receptor antagonist, in prostate cancer cells. Invest New Drugs [Internet] 2020;38(5):1292-302. Available from: http://www.ncbi.nlm.nih.gov/pubmed/32008178

20. McCoy J, Goren A, Cadegiani FA, Vaño-Galván S, Kovacevic M, Fonseca DN, Dorner E, Onety DC, Zimerman RA, Wambier CG. Proxalutamide (GT0918) Reduces the Rate of Hospitalization for COVID-19 Male Outpatients: A Randomized Double-Blinded Placebo-Controlled Trial. Front. Med. I doi: 10.3389/fmed.2021.668698

21. Cadegiani FA, McCoy J, Gustavo Wambier C, et al. Proxalutamide Significantly Accelerates Viral Clearance and Reduces Time to Clinical Remission in Patients with Mild to Moderate COVID-19: Results from a Randomized, DoubleBlinded, Placebo-Controlled Trial. Cureus [Internet] 2021;Available from: https://www.cureus.com/articles/52299-proxalutamide-significantly-acceleratesviral-clearance-and-reduces-time-to-clinical-remission-in-patients-with-mild-tomoderate-covid-19-results-from-a-randomized-double-blinded-placebocontrolled-trial.

22. Flavio A Cadegiani, Daniel N Fonseca, John McCoy, Ricardo A. Zimerman, Fatima NMirza, Michael N Correia, Renan N Barros, Dirce C Onety, Karla Cristina P Israel, Brenda G Almeida, Emilyn O Guerreiro, Jose Enrique M Medeiros, Raquel N Nicolau, Luiza FM Nicolau, Rafael 
X Cunha, Maria Fernanda $\quad$ R Barroco, Patricia $\quad$ S da Silva, Gabriel S Ferreira, Flavio Renan PC Alcantara, Angelo M Ribeiro, Felipe O de Almeida, Adailson A de Souza, Suzyane S do Rosario, Raysa WS Paulain, Alessandra Reis, MarissaLi, Claudia E Thompson, Gerald J Nau, Carlos Gustavo Wambier, Andy Goren. Efficacy of Proxalutamide in Hospitalized COVID-19 Patients: A Randomized, Double-Blind, PlaceboControlled, Parallel-Design Clinical Trial. medRxiv 2021.06.22.21259318; doi:https://doi.org/10.1101/2021.06.22.212593 18.

23. Ranzani OT, Bastos LSL, Gelli JGM, Marchesi JF, Baião F, Hamacher S, Bozza FA. Characterisation of the first 250,000 hospital admissions for COVID-19 in Brazil: a retrospective analysis of nationwide data. Lancet Respir Med. 2021 Apr;9(4):407-418. doi: 10.1016/S2213-2600(20)30560-9. Epub 2021 Jan 15. PMID: 33460571; PMCID: PMC7834889.

24. Marshall JC, Murthy S, Diaz J, et al. A minimal common outcome measure set for COVID-19 clinical research. Lancet Infect Dis [Internet] 2020;20(8):e192-7. Available

from: https://linkinghub.elsevier.com/retrieve/pii/S1473309920304837

25. Pocock SJ, Assmann SE, Enos LE, Kasten LE. Subgroup analysis, covariate adjustment and baseline comparisons in clinical trial reporting: current practice and problems. Stat Med, 2002, vol. 21 (pg. 2917-30). 